\title{
Building a Lattice for School Leadership: Lessons from England
}

Jonathan Supovitz, University of Pennsylvania

The flat structure of American schools is ill-suited to meet today's increasing demands for educational improvement. Even with unprecedented pressure to raise performance, America's schools are still largely organized the way they were a century ago-with a single principal presiding over a largely egg-crated faculty. Is such a thin veneer of instructional leadership sufficient to build the capacity of teachers at each grade level and content area to develop students to reach high expectations? Historically, American schools have addressed this deficit in instructional support with a patchwork of poorly defined roles and responsibilities-under-utilized department chairs, fitful coaching models, and informal teacher leaders who generally lacked the training and authority to influence the practice of their peers. How exactly do these roles fit into contemporary schools' strategies for improving teaching and learning? How can we more systematically build the capacity of school leaders to engage with and overcome the challenges of continuous school improvement?

One place to look for fresh ideas about leadership development is England. Over the past 15 years, educational leaders

Over the past 15 years, educational leaders in England have made several important revisions in the ways leadership is organized in schools, how leaders are developed, and how leadership is integrated into the larger educational infrastructure. There is much that American policymakers might learn from these experiences.

in England have made several important revisions in the ways leadership is organized in schools, how leaders are developed, and how leadership is integrated into the larger educational infrastructure. There is much that American policymakers might learn from these experiences.

This policy brief examines the evolution of the educational leadership development system in England to see what ideas American leaders and policymakers might take from looking transnationally. The brief is based on a more in-depth examination of that leadership development system described in a CPRE research report entitled Building a Lattice for School Leadership: The Top-to-Bottom Rethinking of Leadership Development in England and What It Might Mean for American Education. The research report was based upon a year of research on school leadership in England that included extensive background research, site visits to schools and leadership programs, and over 20 interviews with government officials, teachers and school leaders, university researchers, union officials, and both forprofit and non-profit school leadership providers. 


\section{Evolution of Leadership Development System in England}

England is geographically the size of Alabama but publicly funds about 20,000 schools-equivalent to the number of public schools in California and Texas combined! The story of England's refinement of a leadership system begins in 2000 with the development of a set of clear roles and responsibilities for school leaders at multiple levels of a school, including head teachers (i.e. principals), senior leaders, and middle leaders. Particularly striking from the U.S. perspective is the set of explicit responsibilities for middle leaders to direct-and be accountable for-teaching, learning, and student behavior in subject areas or grade levels within a school. This approach is distinctively different from the American model of teacher leadership; a refined school leadership structure adds depth to the instructional support for teachers and moves responsibility for instructional improvement closer to the classroom. The multiple level leadership structure also creates pathways for teachers to become leaders, and for leaders to develop and refine their skills across their professional careers.

The combination of vertical leadership development and lateral school network support constitutes the lattice of school leadership.
To establish a school leadership development system, in 2000 England's government charged a quasi-governmental organization, the National College of School Leadership, to define the knowledge and skills necessary to lead at each of the three levels and to develop a high quality curriculum to build the capacity of leaders to competently perform at each level. The National College curriculum brought together a rich set of blended learning experiences that culminate in an assessment for a nationally accredited certification for each leadership level. Tens of thousands of school leaders have received national certification.

More recently, the Cameron government has shifted to a more decentralized emphasis by facilitating school networks to enable lateral school exchanges, led by high performing schools. Because these school-level networks are closer to particular problems of practice, they are more grounded and responsive to the specific challenges and needs of participating schools. This combination of vertical leadership development and lateral school network support constitutes the lattice of school leadership.

Additionally, school leadership and effective teaching are central elements of the national school inspection process, which is the cornerstone of the nation's school accountability system. By incorporating school leadership and instructional practice into school performance judgments, the essential role of these elements is reinforced and the signals for what schools should focus on are broadened beyond test performance.

\section{Phases of England's Leadership Development System}

England's efforts to develop school leaders over the past 15 years have roughly occurred in three overlapping phases that largely align with the eras of the Blair (2000-2007) and Cameron (2007-present) governments. Phases one and two were concerted efforts to develop a centralized strategy to specify leadership pathways in schools and develop a system to build the capacity of leaders to follow these pathways. The third, more recent phase has taken a more decentralized approach to using school-led local networks to laterally build leadership capacity. 


\section{Phase 1: Defining leadership roles and developing curriculum ( 2000-2004)}

» National College of School Leadership develops a framework for the knowledge and skill for school leadership at different levels of a school, including:

$\checkmark$ Head Teachers (similar to principals in the U.S.)

$\checkmark$ Senior Leaders (similar to assistant or vice principals in the U.S., but with clearer school-wide responsibilities)

$\checkmark$ Middle Leaders (teachers responsible for the development of teachers at a grade level, grade-range (i.e., $\mathrm{K}-2,3-5$ ), or subject area, and accountable for their performance).

»Based upon the framework of knowledge and skills at each of these levels the National College develops an associated curriculum that combines theory and practice, face-to-face sessions as well as online mixed-media assignments, projects designed to connect out-of-school learning, and in-school work that focuses on:

$\checkmark$ Instructional leadership: leading and improving teaching

$\checkmark$ Operational management: managing school systems and processes

$\checkmark$ Strategic leadership: working with people, coaching and leading change

Summary of National College Module Map, 2012

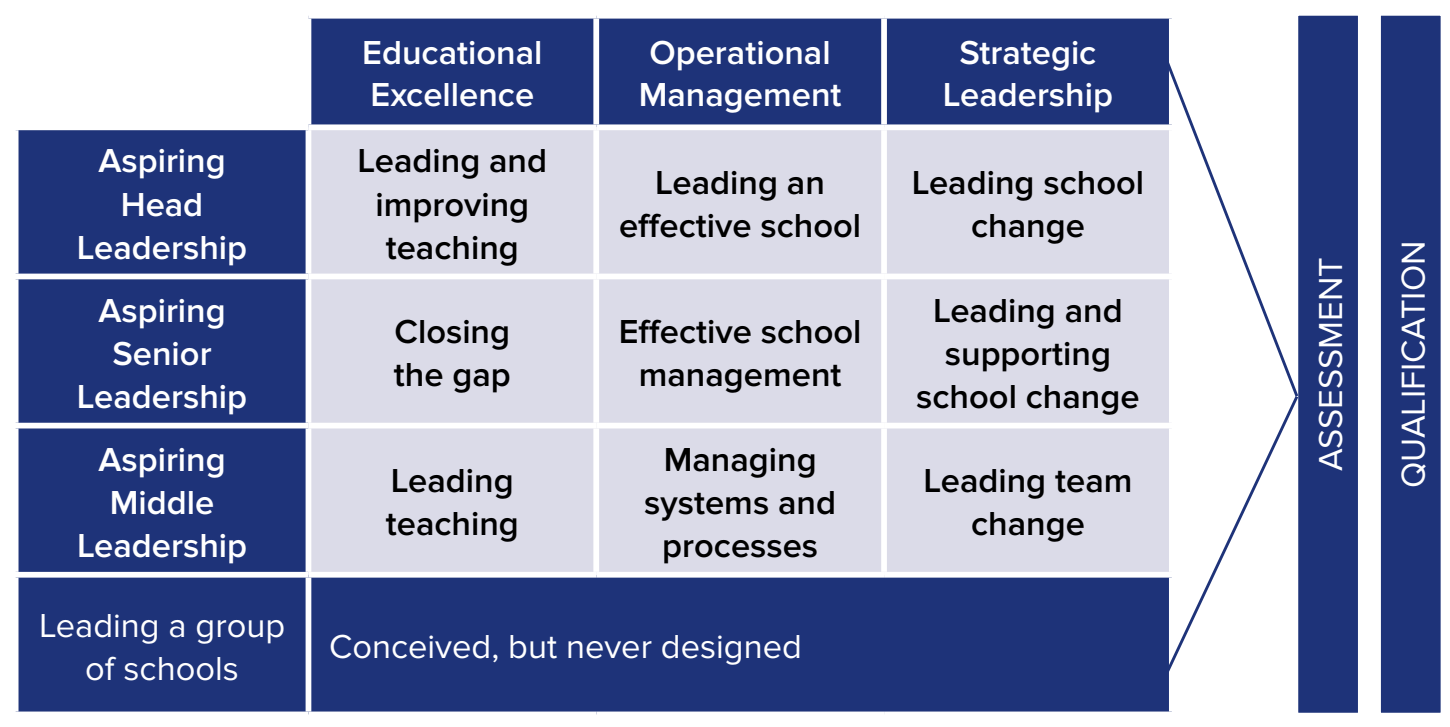

\section{Phase 2: Integrating leadership system into the national incentive structures ( 2004-2012)}

»National qualifications is developed for head teachers, senior leaders, and middle leaders that were based on a portfolio developed during participation in the leadership curriculum, which provided incentives for leaders to develop themselves and a certification of leadership preparation.

» Leadership is integrated into the nation's school accountability system. Rather than relying primarily on a test-based accountability system, England refined its school-inspection system to focus not just on the outcomes of education, but the processes that produce student outcomes. The system emphasizes four elements: student behavior and discipline, quality of teaching, leadership and management, and student outcomes. 


\section{Phase 3: Expanding providers and fostering school networks ( 2012-Present)}

» Increasing movement of schools away from local authorities (akin to school districts in U.S.) towards local academies, which are similar to U.S. charter schools.

» Shifting emphasis towards a "school led system" in which schools, not the central government, lead capacity building and search for innovation in the system.

»Expansion of the market of school leadership development providers by initially licensing National College curriculum to qualified providers and planning to move the curriculum into the public domain.

» Increasing focus on government stimulated networks of schools led by high-performing schools, to organize professional learning experiences for members, build local capacity, and promote crossschool learning.

\section{The Lattice for School Leadership}

The concept of a lattice for school leadership is the careful integration of both formal and network learning opportunities for leaders at multiple levels of a system. It features a centrally developed, high quality leadership development program combined with lateral social networks to support schools and school leaders. The first set of more formal learning experiences builds educational leader capacity to enact a defined set of knowledge, skills, and competencies at multiple system levels through a high quality curriculum that combines theory and practice within a rich set of blended learning experiences.

The second set of experiences involves the building of robust networks of schools that collaborate on problems of leadership practice emanating from actual school need, grounding learning in the challenges of educator practice, and making development more localized, ongoing, and sustained. A distinct advantage of the lattice approach is that formal and network learning complement each other by tapping different sources of valued knowledge, curricular approaches, and learning theories.

\section{The Lattice for School Leadership Framework}

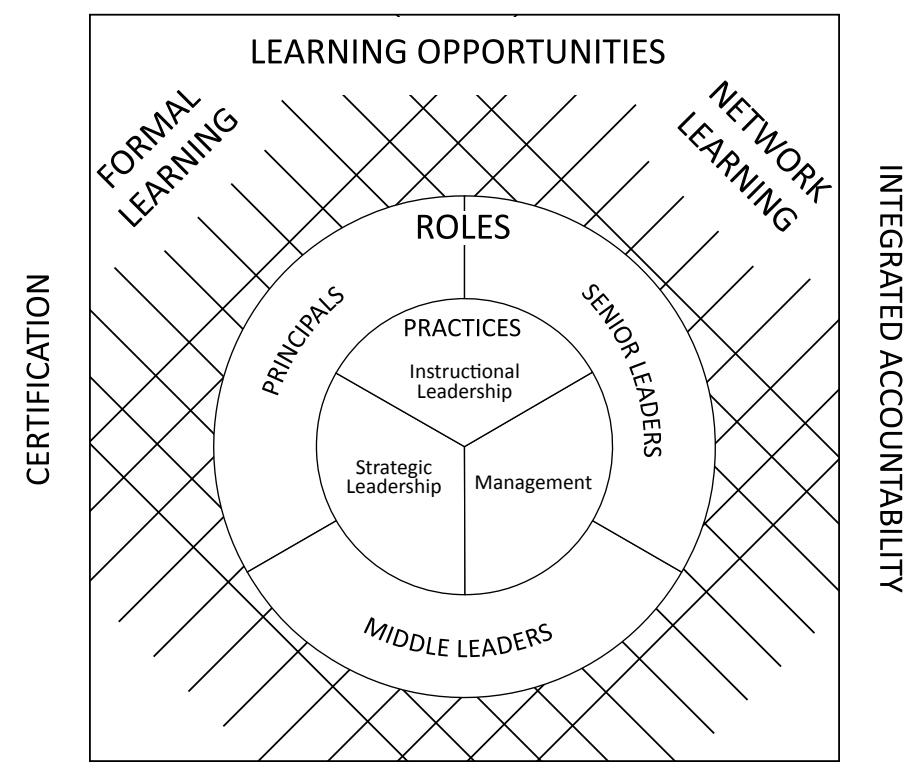

A distinct advantage of the lattice approach is that formal and network learning complement each other by tapping different sources of valued knowledge, curricular approaches, and learning theories. 


\begin{tabular}{|c|l|l|}
\hline \multicolumn{1}{c|}{$\begin{array}{c}\text { Formal leadership Learning } \\
\begin{array}{c}\text { Source of Valued } \\
\text { Knowledge }\end{array}\end{array}$} & $\begin{array}{l}\text { Externally derived research and theory- } \\
\text { based identification of knowledge, skills and } \\
\text { competencies considered to be necessary } \\
\text { for effective school leadership }\end{array}$ & $\begin{array}{l}\text { Craft derived, emanating from leaders' } \\
\text { experiences and grounded in problems of } \\
\text { practice }\end{array}$ \\
\hline $\begin{array}{l}\text { Static curriculum combines theory and } \\
\text { practice, face-to-face sessions and online } \\
\text { mixed-media assignments, projects } \\
\text { designed to connect out-of-school learning } \\
\text { and in-school work }\end{array}$ & $\begin{array}{l}\text { Flexibly and experientially based and } \\
\text { collaboratively constructed }\end{array}$ \\
\hline $\begin{array}{c}\text { Underlying Learning } \\
\text { Theory }\end{array}$ & $\begin{array}{l}\text { Combining behavioral and constructivist } \\
\text { learning }\end{array}$ & Socially situated learning \\
\hline
\end{tabular}

These complementary elements of leadership development are carefully enmeshed in a system that provides clear responsibilities for multiple levels of leadership within schools, incentives for identifying and grooming leadership within schools, pathways for leadership progression, and certification for leader attainments. All of these elements are supported by an accountability structure that emphasizes the contribution of school leadership and teaching to school improvement.

The concept of a lattice of school leadership also challenges educational leaders and policy makers to hold multiple, sometimes competing, conceptions of professional learning in their heads. Such a system combines centralized and decentralized structures, formal and social learning approaches, and multiple system actors.

\section{Implications for Policymakers}

Almost every study of school improvement, whether anecdotal or systematic, cites the importance of leadership, yet we tend to think of leadership development and support as an individual trait rather than a design principle. The story of England's leadership development system is an instructive case of how to use the levers of policy to create a vision for school leadership, expand and formalize leadership pathways within schools, formulate models to build leadership capacity, attend to incentives to stimulate demand, and carefully push on the right pressure points to constructively focus schools on the important role of leadership in the improvement of teaching and learning. In taking these steps, the English have enmeshed school leadership into the core processes of school improvement.

It is worthwhile for American policymakers to consider the following key components of England's leadership system and their implications for U.S. educational policy:

» Formalizing multiple leadership positions within a school beyond the principal to include both senior and middle-level leaders, which (a) formally distributes leadership responsibilities, (b) helps to better support and monitor instructional improvement efforts, (c) creates career development pathways for school professionals; 


\section{Almost every study of school improvement, whether anecdotal or systematic, cites the importance of leadership, yet we tend to think of leadership development and support as an individual trait rather than a design principle.}

» Identifying a broadly recognized set of leadership competencies that are targeted to each of the leadership levels, which creates a clear set of knowledge and skills necessary for different leadership positions;

»Developing both formal and network learning opportunities that allow for learning to be expert and peer-led, structured and flexibly organized, and focus on both classical knowledge and the craft skills and experience that come from addressing situated problems of practice;

»Creating widely recognized certifications for school leaders that are aligned with the leadership competencies and professional learning experiences that serve as incentives for leadership progression;

» Integrating the leadership function into the broader accountability system to provide appropriately targeted pressure on school leaders to advance their leadership competencies and to promote the role of leadership in school improvement.

Finally, it is worth noting that identifying sensible ideas is a far cry from successfully incorporating them into a different culture with its own unique education system. Each of these ideas has serious implications for the current system of private, university, and public leadership development providers as well as the incentive and accountability structures that surrounds schools and nudges the priorities and behaviors of school leaders. While it is important that these ideas enter the policy debate, the hard thinking, planning, and resource allocation that would need to occur for any of them to be fruitfully incorporated into American education should not be underestimated. Even so, they are worthwhile to bolster the educational leadership system that is so integral to improving educational performance.

\section{Questions? Find More Info}

cpre.org

The Consortium for Policy Research in Education (CPRE) brings together education experts from renowned research institutions to contribute new knowledge that informs Prek-20 education policy and practice. Our work is peer-reviewed and open-access. Visit cpre.org.

Contact Jonathan Supovitz at jons@gse.upenn.edu.

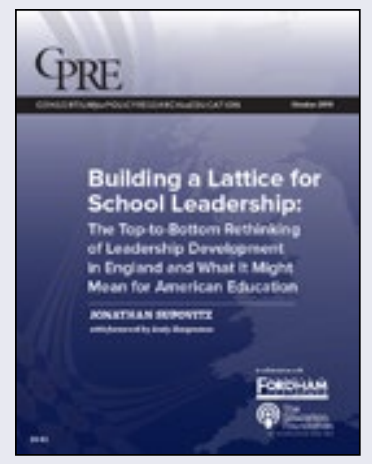

This brief was derived from the full report:

Supovitz, J. (2014). Building a Lattice for School Leadership: The Top-to-Bottom Rethinking of Leadership Development in England and What it Might Mean for American Education. Research Report (\#RR-83). Philadelphia:Consortium for Policy Research in Education, University of Pennsylvania.

Download the full report at cpre.org/latticeforschoolleadership. 